\title{
Is Regulation to Blame for the Decline in American Entrepreneurship?
}

\author{
Nathan Goldschlag 1 \\ George Mason University \\ Alexander Tabarrok \\ Department of Economics \\ George Mason University
}

\begin{abstract}
Mounting evidence suggests that economic dynamism and entrepreneurial activity are declining in the United States. Over the past thirty years, the annual number of new business startups and the pace of job reallocation have declined significantly. A variety of causes for these trends have been suggested, including an increasing ability of firms to respond to idiosyncratic shocks, technology induced changes in the costs of hiring and training, and increasing regulation. This research combines data from the Statistics of U.S. Businesses, which contains measures of the decline in economic dynamism, with RegData, a novel dataset leveraging the textual content of the Code of Federal Regulations. RegData contains annual industry level measures of the stringency of regulation. By combining these data, we are able to estimate the extent to which changes in the level of federal regulation can explain decreasing entrepreneurial activity and dynamism. We find that Federal regulation has had little to no effect on declining dynamism.
\end{abstract}

\section{Introduction}

The movement of resources from low-productivity firms to high-productivity firms is a key driver of economic efficiency and growth (Syverson 2011, Hseih and Klenow 2009, Bartelsman, Haltiwanger and Scarpetta 2013). Startups contribute significantly to this reallocation process. Many startups fail within a few years, so startups contribute to both job creation and job destruction. A small subset of startups, however, grow quickly, and contribute disproportionally to net job growth and to improvements in industry productivity. Workers also move among firms at tremendous rates meaning gross job creation and destruction is much larger than net job creation (Davis, Haltiwanger, Schuh 1998, Decker, Haltiwanger, Jarmin \& Miranda 2014).

\footnotetext{
${ }^{1}$ Disclaimer: Opinions and views expressed in this paper represent the views of the authors only and should not be taken an representing any associated organizations.
} 
Although the US economy exhibits a rapid pace of startups, job creation, and job destruction, these forces have been in decline for nearly three decades with a possible increase in the rate of decline in the past decade. The dynamism decline is robust, appearing in a variety of data including the Job Openings and Labor Turnover data, the Bureau of labor Statistics' Business Employment Dynamics data, and business dynamics measures from the Census Bureau's Business Dynamics Statistics. The decline in dynamism is associated with reductions in productivity, real wages and employment (Davis and Haltiwanger 2014). The magnitude and pervasiveness of the decline, coupled with the theoretical importance of reallocation for efficiency and growth, underscores the importance of understanding and explaining the trend towards a less dynamic U.S. economy.

A variety of explanations for the decline have been suggested, including an increasing ability of firms to respond to idiosyncratic shocks, technology induced changes in the costs of hiring and training, increasing consolidation, slowing population growth, and increased regulation making reallocation slower and more costly (Decker, Haltiwanger, Jarmin \& Miranda 2014, Hathaway \& Litan 2014). This research uses a novel source of data on federal regulations to determine the extent to which the stringency of federal regulations affects the severity of the decline in dynamism at the industry level.

Regulation can increase barriers to entry, tax job destruction, and slow the reallocation of capital. Hopenhayn and Rogerson's (1993) general equilibrium analysis shows that increasing adjustment costs, for example through regulation, not only reduces job destruction, but also decreases job creation, startups, and productivity. The empirical literature using cross-country studies has shown that employment protection legislation and other labor market institutions could explain the differential performance between American and European labor markets (Freeman, 2005). Other studies have shown that product and labor market regulations slow factor adjustment and cause allocative inefficiencies (Eslava, Haltiwanger, Kugler, \& Kugler, 2010). Similarly, evidence suggests that entry deterrence regulations can slow employment growth (Bertrand \& Kramarz, 2002). Thus, regulation is a plausible candidate for explaining declining dynamism although the pervasiveness of the decline across industries does suggest that deeper factors may also be at work. 


\section{Economic Dynamism}

The rich firm-level dynamics of the US economy, with many firms entering and exiting, have been slowing since the 1980s. Figure 1 shows the substantial decline in startup and exit rates over the past several decades. The startup rate fell from 13.7 percent in 1980 to 11.7 percent just before the Great Recession, with the exit rate falling from 12.1 percent in 1980 to 10.3 percent in 2007. Though startups are important for net job creation, it is not the case that all small or all young firms contribute to job creation. There is a significant population of stagnant firms that are small and experience no employment growth. Moreover, most startups fail-50 percent of jobs generated by an entering cohort of firms are lost after five years. However, conditional on survival some firms experience large employment growth, contributing disproportionately to net job creation.

Figure 1: US Annual Startup and Exit Rates

\section{Startup and Exit Rates \\ 1980-2011}

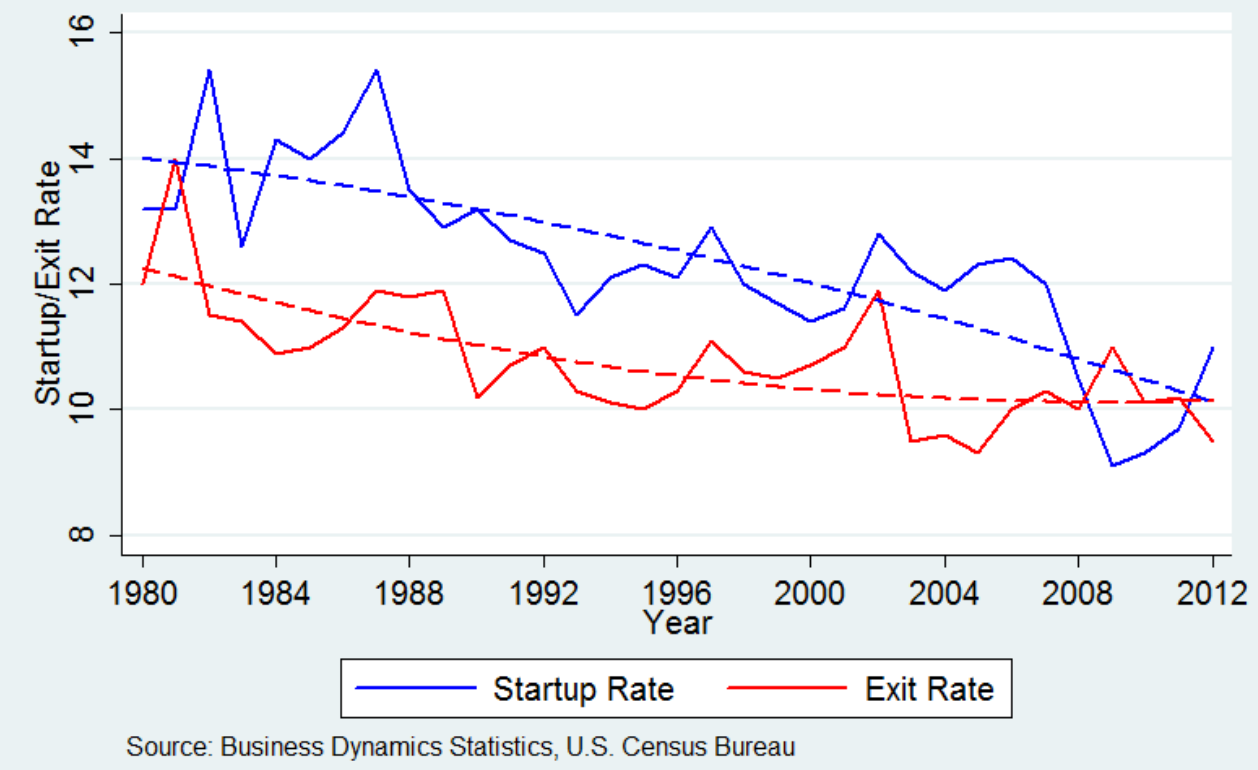

Figure 2 shows the annual job creation and destruction rates for 1980 through 2010. The job creation rate fell from an average of 18.9 percent in the late 1980s to 15.8 percent prior to the Great Recession. Likewise, the job destruction rate fell from 16.1 percent in the late 1980s to just 13.4 percent in the same pre-Great Recession period. These declines are robust to different specifications of dynamism and at both 
the firm and establishment level in a variety of data sources. In addition to less job creation and destruction, Davis, Faberman, Haltiwanger, Jarmin, and Miranda (2010) use Bureau of Labor Statistics data to show that the pace of labor flows through the unemployment pool have declined since the 1980s. Similarly, Davis, Faberman, and Haltiwanger (2012) show a decline in the pace of excess worker reallocation in the Job Openings and Labor Turnover data.

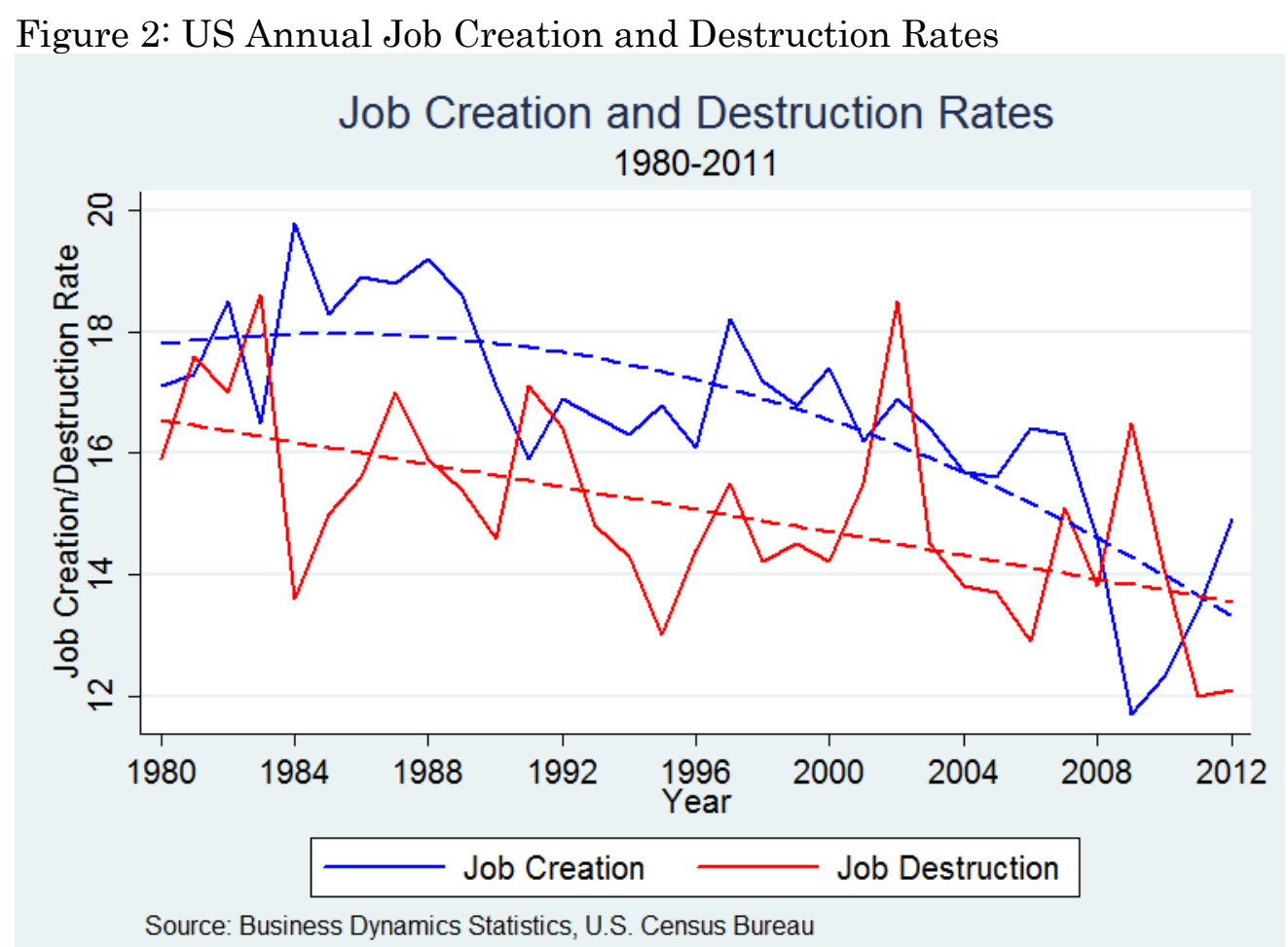

The slowing entrepreneurial activity is also affecting firm-level distributions such as firm age. The Business Dynamics Statistics (BDS) data shows a declining startup rate and stagnant startup size (Haltiwanger, Jarmin, \& Miranda, 2013). These trends are placing downward pressure on the share of economic activity attributed to young firms, leading to an aging firm population. Firms aged five years or less accounted for 47 percent of all firms in the late 1980s, which fell to 39 percent prior to the Great Recession. In contrast, firms aged 16 or more years have alone increased in share; increasing by $50 \%$ from $22 \%$ of all firms in 1992 to $34 \%$ of all firms by 2011 (Hathaway and Litan 2014). Job creation by firms aged five years or less fell from 39 percent in the 1980s to 33 percent of all new jobs before the Great 
Recession. Since young firms tend to contribute disproportionately to both job creation and destruction, the decreasing representation of young firms tends to decrease the overall rates of job creation and destruction (Decker, Haltiwanger, Jarmin \& Miranda 2014).

Measures of economic dynamism are also intimately related to productivity. The literature on productivity has shown persistent differences in productivity across firms within industries. The extent of these differences is surprising-manufacturing firms at the 90th percentile of productivity produce twice as much as firms in the 10th percentile (Syverson 2004). Perhaps less surprising, higher productivity firms are more likely to survive (Syverson 2011). Reallocation in the form of entry, exit, expansions, and contractions have significant effects on productivity. Foster, Haltiwanger, and Krizan (2005) show that, within the massive restructuring of the retail trade section in the 1990s, nearly all of the labor productivity growth was driven by more productive establishments displacing less productive establishments.

Regulation need not reduce dynamism. A tax, for example, might reduce the level of economic activity but in equilibrium need not reduce the rate of firm entry or exit or impede the reallocation process that shifts resources from low productivity to high productivity firms. Specific types of regulation, however, can reduce dynamism with resulting large costs in productivity. Hopenhayn and Rogerson (1993), for example, show that a tax on job destruction in the form of employment protection legislation, reduces employment and consumption and acts as a drag on productivity. Similarly, several studies of specific incidences of deregulation have shown that reducing the regulatory burden induces efficiency enhancing reallocation by increasing the probability that low productivity firms will exit, increasing job reallocation rates, and increasing capital formation (Olley and Pakes 1996, Eslava, Haltiwanger, Kugler and Kugler 2010, Davis and Haltiwanger 2014).

Improvements to firm-level data infrastructures such as the Longitudinal Business Database (LBD) have produced a flurry of empirical research describing the secular decline in dynamism. Despite the importance of the decline, few papers have investigated its cause. In the following sections, we will investigate the extent to which federal regulations are to blame for the trends in entrepreneurship and economic dynamism. 


\subsection{Regulation - RegData}

To measure the stringency of federal regulation we draw on RegData, a new and innovative source of federal regulation data (Al-Ubaydli and McLaughlin, 2013). Prior studies of regulation have relied upon crude measures such as file sizes, page counts, and word counts of the Federal Register or Code of Federal Regulations (Mulligan \& Shleifer 2005; Coffey et al. 2012; Dawson \& Seater 2008). RegData provides an annual industry-level measure of regulation that is based directly on the text of the Code of Federal Regulations.

The Code of Federal Regulations (CFR) contains annual snapshots of the stock of all federal regulations in effect in a given year. The CFR is divided into sections, including titles, chapters, subchapters, parts, and subparts. To measure regulatory stringency, Al-Ubaydli and McLaughlin (2014) comb the CFR and count the number of restrictive terms or phrases including "shall," "must," "may not," "prohibited," and "required". In this way, each section of the CFR can be assigned a count of restrictions.

Although the titles of the CFR often have suggestive names such as "Energy", "Banks and Banking", and "Agriculture", a single regulation in any CFR section can affect many industries so there is no simple way to connect the number of regulatory restrictions by section to an industry. To solve this problem Al-Ubaydli and McLaughlin draw on developments in machine learning and natural language processing techniques.

Algorithms have been produced that can classify images. Google's image search, for example, is trained on a set of tagged images and it is then able to classify images out-of-sample based on the training set. Classification algorithms for text-a much simpler problem-work in a similar way. After being exposed to a set of already-classified training documents the algorithms recognize patterns in "wild" documents and classify them into categories according to probabilities. These kinds of techniques have become standard in the computer science and machine learning literature (Witten and Frank 2005).

Al-Ubaydli and McLaughlin (2014) train their algorithm on long-form descriptions of each industry found in the North American Industry Classification System (NAICS) and on Federal Register (FR) entries that explicitly identify affected industries by NAICS code. Whereas the CFR contains the stock of federal 
regulations, the FR captures the flow of new regulations and rules proposed by federal agencies. The training set is then used to probabilistically match text in the CFR to each industry. Thus, each section in the CFR has a regulatory restrictiveness count and each section can be weighted by the probability that it is about or affects each industry. The restrictions and probability weights are then aggregated to produce an index of regulatory stringency by industry and year. An example of the regulatory text from the CFR, along with its restrictive term count and NAICS probability associations, can be found in Appendix A.

Figure 3 shows the steady increase in the total number of restrictive words and phrases in the CFR by year. The popular notion that regulation has been increasing over the past several decades can be seen clearly in the text of the CFR.

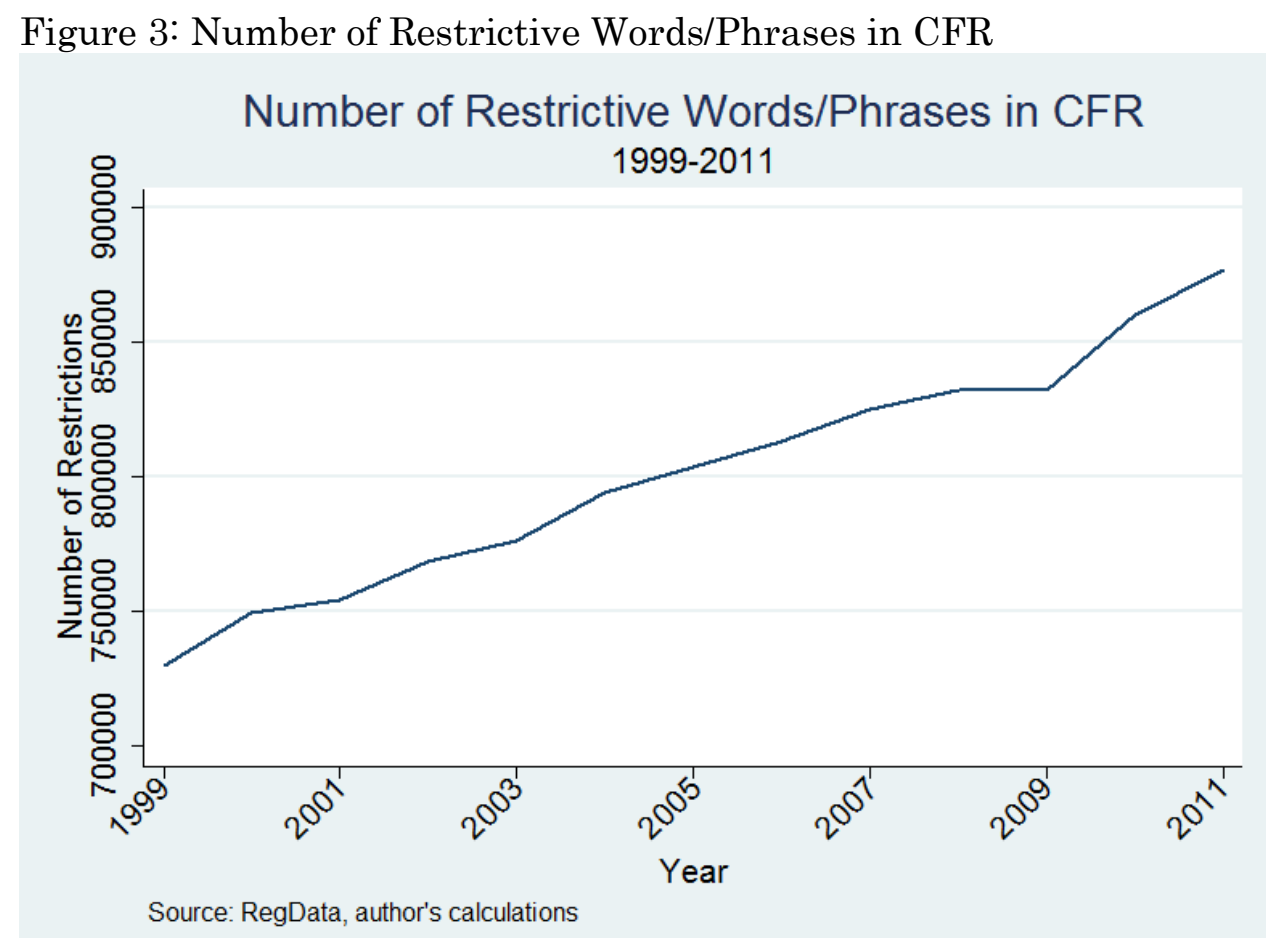

Table 1 lists the most and least regulated industries according to the index. Air Transport is by far the most regulated industry by this measure-this means that the text in the CFR that impacts air transport contains many restrictive words such as "must" and "prohibited", and also that there are many sections of the CFR that impact air transport. Hospitals, truck transportation, and utilities are also heavily regulated, as expected. We usually think of trucking as having been deregulated 
circa 1977-1982 but that was primarily price deregulation. The index suggests that in most respects trucking remains a highly regulated industry. Among the least regulated industries are light manufacturing, and miscellaneous retailers. The large variation in regulation by industry provides scope to identify the possible influence of regulation on dynamism.

Table 1: Regulatory Stringency by Industry (Average 1999-2011)

\begin{tabular}{lclc}
\hline Least Regulated & & Most Regulated & \\
\hline Name (NAICS Code) & $\begin{array}{c}\text { Stringency } \\
\text { Index }\end{array}$ & Name (NAICS Code) & $\begin{array}{c}\text { Stringency } \\
\text { Index }\end{array}$ \\
\hline Furniture \& Related (337) & 14.28 & Air Transport (481) & 137,259 \\
Machinery Manuf. (333) & 14.28 & Hospitals (622) & 58,436 \\
Electrical Equip Manuf. (335) & 26.68 & Truck Transportation (484) & 44,920 \\
Computer Electronic Manuf. (334) & 111.19 & Utilities (221) & 44,388 \\
Miscellaneous Retailers (453) & 234.17 & Securities, Financial & 41,304 \\
& & Investments (523) & 4 \\
\hline
\end{tabular}

Table 2 below shows the top federal agencies by mean regulatory impact between 1999 and 2011. The Environmental Protection Agency is responsible for a greater portion of regulations than any other agency. Other agencies with notable regulatory incidence are the Department of Homeland Security, Internal Revenue Service, and the Occupational Safety and Health Administration.

Table 2: Regulatory Stringency by Agency (Average 1999-2011)

\begin{tabular}{lc}
\hline Agency Name & Stringency Index \\
\hline Environmental Protection Agency & 141,529 \\
Department of Homeland Security & 41,987 \\
Internal Revenue Service & 41,957 \\
Occupational Safety and Health Administration & 30,012 \\
Federal Communications Commission & 24,226 \\
Federal Aviation Administration & 20,543 \\
Food and Drug Administration & 17,964 \\
Nuclear Regulatory Commission & 15,660 \\
Department of Transportation & 13,256 \\
Department of Agriculture & 13,186 \\
\hline
\end{tabular}

While the nominal values of the regulatory index bear little meaning, the relative values of the regulatory stringency index capture well the differences in regulation over time, across industries, and across agencies. 


\subsection{SUSB-Regulation Panel}

Statistics of U.S. Businesses (SUSB) is a public use ${ }^{2}$ annual dataset containing detailed information on establishments, employment, and payroll by geographic area, industry (NAICS 4-digit), and firm size. SUSB is derived from the Business Register, which contains the Census Bureau's most complete, current, and consistent data for the universe of private U.S. business establishments. In addition to tabulations for firms, establishments, employment, and payroll, SUSB also provides data on year-to-year employment changes by births, deaths, expansions, and contractions. These employment change tabulations are available for 1992 and 1997 through 2011. By combining SUSB and RegData, we can gain a better understanding of the relationship between federal regulation and economic dynamism.

One limitation of the SUSB data with respect to the analysis to follow is that establishment birth counts in SUSB show positive bias in Economic Census years as some births are incorrectly timed due to census processing activities. ${ }^{3}$ As explained in the following section, any bias these year specific effects might have will be controlled via year fixed effects. Another drawback of the SUSB data is the lack of firm age. The subsequent analysis will be unable to address the declining share of employment for young firms as evidence for the secular decline in dynamism and entrepreneurship. A possible advantage of the SUSB is that the measures of dynamism are at the establishment level rather than at the firm level. Thus, we can take into account the effects of regulation on any expansion regardless of the source (see also Goldschlag and Tabarrok 2015 on different measures of entrepreneurship).

The industry classification code used in the employment change data varies over time, making it necessary to translate between NAICS vintages. The Census Bureau provides concordances between subsequent iterations of the NAICS classification system. In some cases multiple concordances must be combined to arrive at a

\footnotetext{
2 https://www.census.gov/econ/susb/

${ }^{3}$ Other sources of business dynamics such as Business Dynamic Statistics (BDS) exhibit smoother birth and death time series because it is derived from the Longitudinal Business Database (LBD), which is subjected to algorithms that re-time incorrect births and deaths (Haltiwanger, Jarmin \& Miranda 2009). Nevertheless, the correlations between SUSB measures and BDS measures of dynamism over the same period are very high with correlations of $.99, .97$ and .91 for job creation, destruction and startups respectively.
} 
consistent classification scheme. To translate between different NAICS we use weights, assuming equal weighting for each match at the 4-digit NAICS level. The SUSB data described above use 4-digit NAICS, so the 6-digit NAICS concordances regulation data are aggregated to create 4-digit to 4-digit NAICS mappings.

The final SUSB-RegData panel contains observations between 1999 and 2011. The variables of interest, which will be used as measures of entrepreneurship and dynamism, are startups, job creation, and job destruction. Figure 4 shows average startup rate versus the average regulation index by industry. The regulatory index axis is plotted on a log scale due to the wide variation in the regulation across industries. The fitted line suggests a slightly positive relationship between regulation and startups. Figure 5 shows the relationship between job creation rates and our regulatory index. Again, job creation appears slightly positively correlated with regulation at the industry level.

Figure 4: Startup Rates vs. Regulatory Stringency

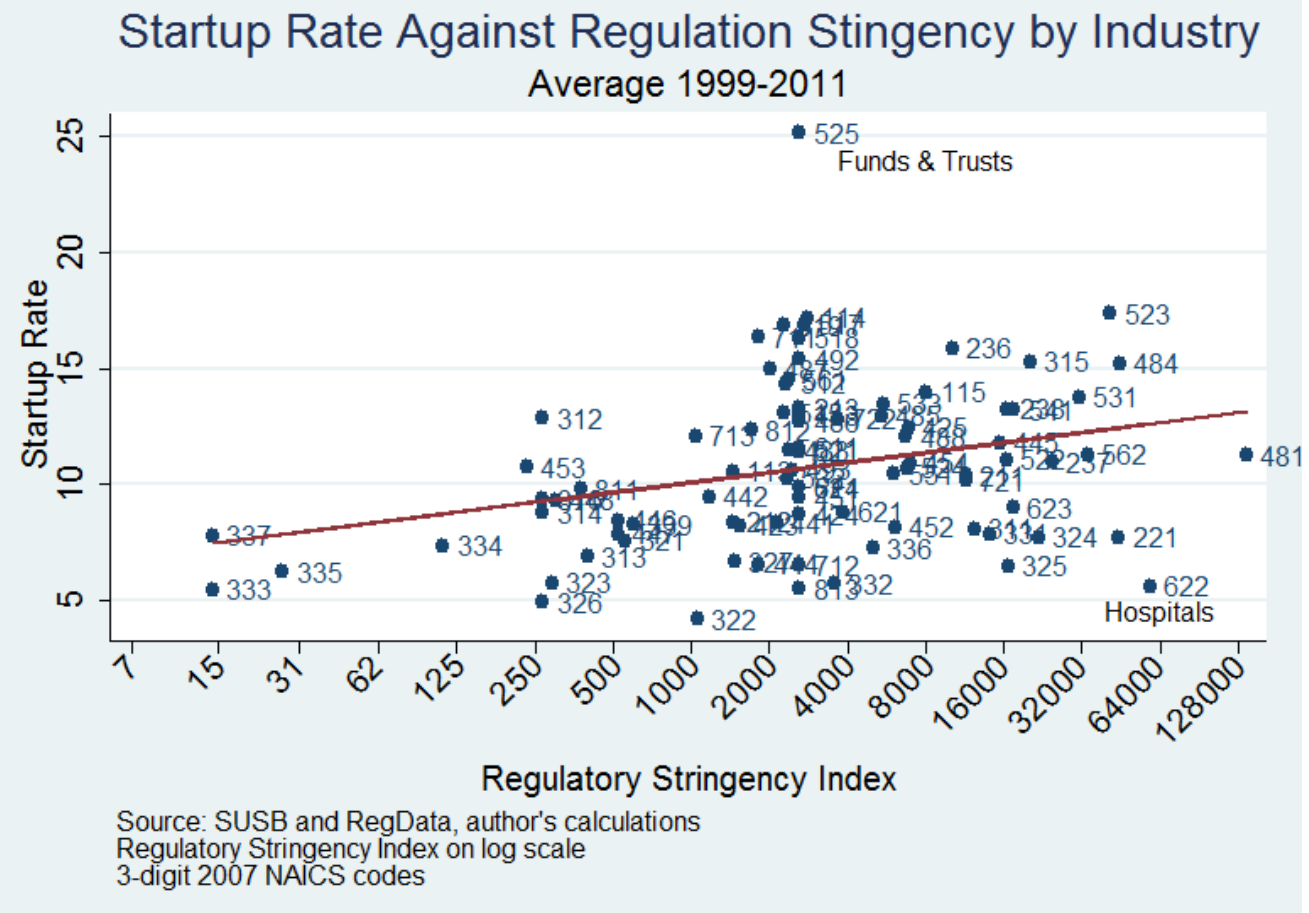


Figure 5: Job Creation Rates vs. Regulatory Stringency

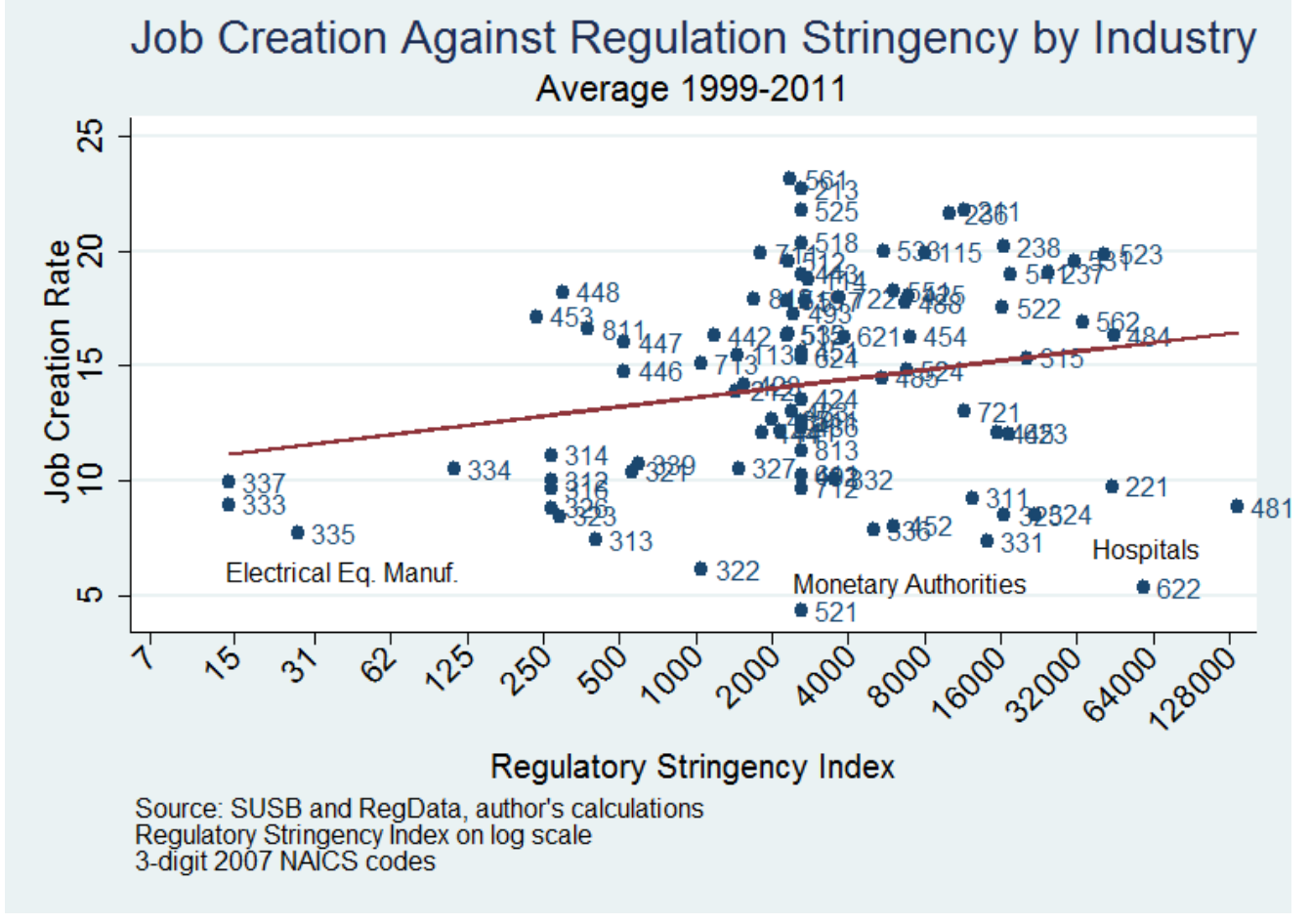

The apparently positive relationship between startups and job creation and regulation may be the result of endogeneity. High dynamism industries may be more likely to attract scrutiny and regulation. The analysis in the next section will control for year and industry effects to reveal the relationship between regulation and economic dynamism within an industry over time.

\section{Methods and Results}

To investigate the potential role of federal regulation in the decline in economic dynamism we estimate the effect of our regulatory stringency index by NAICS on several key measures of dynamism and entrepreneurship. Year and industry fixed 
effects are included to capture idiosyncratic changes in dynamism by year and industry that are independent of the level of federal regulation. We estimate the following fixed effects regression model,

$$
Y_{t, n}=\beta_{0}+\beta_{1} \operatorname{Reg}_{t, n}+\beta_{2} X_{t, n}+\lambda_{t}+\gamma_{n}+\varepsilon_{t, n}
$$

Where $Y_{t, n}$ is the measure of dynamism at time $t$, for 3 -digit NAICS $n$. Measures of dynamism include: startup rate, job creation rate, and job destruction rate. Startup rate is calculated as 100 times the number of establishments created at time $t$ divided by the Davis-Haltiwanger-Schuh (DHS) denominator, which is the mean number of establishments for times $t$ and $t-1$. The DHS denominator attempts to control for transitory shocks from affecting the relationship between net growth from t-1 to t and size (Davis, Haltiwanger, \& Schuh 1998). Job creation and destruction rates are calculated as 100 times the number of jobs created (destroyed) divided by the mean employment for times $\mathrm{t}$ and $\mathrm{t}-1$. $\operatorname{Reg}_{t, n}$ is the regulatory stringency index at time $t$, in 3 -digit 2007 NAICS $n$. Finally, $\lambda_{\mathrm{t}}$ and $\mathrm{Yn}_{\mathrm{n}}$ are fixed effects for time and industry category respectively. Year fixed effects will control for economy-wide variation in economic dynamism. Fixed effects by year will also control for any upward bias in the SUSB data due to incorrectly timed births and deaths stemming from economic census activities. Industry fixed effects will control for changes in dynamism due to industry specific conditions that are unrelated to our measure of regulation.

Estimation results are shown in Table 3. After controlling for year and industry fixed effects, our regulatory stringency index shows no effect on measures of economic dynamism. Regulation appears to have no significant effects on startups, job creation, or job destruction. It could be the case that the negative effects of regulation take years to materialize. To verify whether this is the case we add the regulation index $t-1$ and $t-2$. The results suggest, however, that lagged regulation indices are no better able to account for the decline than regulation at time $t$. (In separate results not reported here we show that this remains true using t-1 or t-2 in place of regulation at time t.)

Table 3: Dynamism and Regulatory Stringency

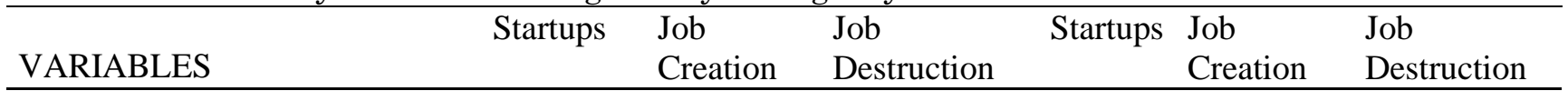




\begin{tabular}{lcccccc} 
Log Regulatory Stringency & 0.241 & 0.0975 & 0.0782 & 0.409 & -0.776 & -0.0589 \\
& $(0.786)$ & $(1.427)$ & $(1.413)$ & $(0.681)$ & $(1.068)$ & $(1.237)$ \\
Log Reg Stringency (-1) & & & & -0.503 & 0.707 & 0.696 \\
& & & & $(0.665)$ & $(0.952)$ & $(0.990)$ \\
Log Reg Stringency (-2) & & & & 0.341 & 0.900 & -0.678 \\
& & & & $(0.654)$ & $(0.992)$ & $(0.982)$ \\
Constant & 8.771 & 14.91 & 13.57 & 8.739 & 9.119 & 14.48 \\
& $(6.187)$ & $(11.24)$ & $(11.11)$ & $(8.146)$ & $(15.07)$ & $(14.20)$ \\
& & & & & & \\
Observations & 1,118 & 1,077 & 1,075 & 1,118 & 1,077 & 1,075 \\
R-squared & 0.188 & 0.302 & 0.283 & 0.188 & 0.303 & 0.283 \\
Number of Industries & 86 & 86 & 86 & 86 & 86 & 86 \\
Industry FE & Yes & Yes & Yes & Yes & Yes & Yes \\
Year FE & Yes & Yes & Yes & Yes & Yes & Yes \\
\hline \multicolumn{2}{r}{} & Robust standard errors in parentheses & & &
\end{tabular}
$* * * \mathrm{p}<0.01, * * \mathrm{p}<0.05, * \mathrm{p}<0.1$

Table 4 breaks establishments into three classes, small (less 1-9 employees), medium (10-499) and large (>500) and looks at job creation and destruction within these classes. Negative effects are largest for small firms which is plausible but no results are statistically significant.

Table 4: Regulatory Stringency and Dynamism by Firm Size

\begin{tabular}{|c|c|c|c|c|c|c|}
\hline & \multicolumn{2}{|c|}{ Small $<10$} & \multicolumn{2}{|c|}{ Medium 10-499 } & \multicolumn{2}{|c|}{ Large $>499$} \\
\hline VARIABLES & $\begin{array}{c}\text { Job } \\
\text { Creation } \\
\end{array}$ & $\begin{array}{c}\text { Job } \\
\text { Destruction } \\
\end{array}$ & $\begin{array}{c}\text { Job } \\
\text { Creation } \\
\end{array}$ & $\begin{array}{c}\text { Job } \\
\text { Destruction } \\
\end{array}$ & $\begin{array}{c}\text { Job } \\
\text { Creation }\end{array}$ & $\begin{array}{c}\text { Job } \\
\text { Destruction } \\
\end{array}$ \\
\hline Log Regulatory Stringency & $\begin{array}{l}-11.47 \\
(9.208)\end{array}$ & $\begin{array}{l}-3.528 \\
(3.373)\end{array}$ & $\begin{array}{l}0.0847 \\
(2.034)\end{array}$ & $\begin{array}{l}-0.630 \\
(1.860)\end{array}$ & $\begin{array}{l}-2.046 \\
(2.483)\end{array}$ & $\begin{array}{c}0.618 \\
(2.095)\end{array}$ \\
\hline Constant & $\begin{array}{c}117.2 \\
(71.94)\end{array}$ & $\begin{array}{l}44.90 * \\
(26.39)\end{array}$ & $\begin{array}{c}12.82 \\
(15.97)\end{array}$ & $\begin{array}{c}17.50 \\
(14.56)\end{array}$ & $\begin{array}{c}29.29 \\
(19.52)\end{array}$ & $\begin{array}{c}6.885 \\
(16.49)\end{array}$ \\
\hline Observations & 1,022 & 1,021 & 1,063 & 1,066 & 993 & 985 \\
\hline R-squared & 0.055 & 0.015 & 0.073 & 0.147 & 0.207 & 0.168 \\
\hline Number of Industries & 86 & 86 & 86 & 86 & 85 & 85 \\
\hline Industry FE & Yes & Yes & Yes & Yes & Yes & Yes \\
\hline Year FE & Yes & Yes & Yes & Yes & Yes & Yes \\
\hline
\end{tabular}

Similarly, the primary negative impacts of regulation may be in the extent to which they change over time, causing firms to incur costs to readjust to new rules. Table 5 indicates that shifting focus to the year over year percent change in the regulation index does not suggest that regulation is a major factor contributing to the decline in dynamism. 
Table 5: Dynamism and Regulatory Change

\begin{tabular}{lccc}
\hline VARIABLES & Startups & Job Creation & Job Destruction \\
\hline \multirow{3}{*}{ Annual Change in Reg Stringency } & & & \\
& 0.331 & -1.274 & 0.00358 \\
Constant & $(0.511)$ & $(0.860)$ & $(0.892)$ \\
& $10.67 * * *$ & $15.62^{* * *}$ & $14.19^{* * *}$ \\
& $(0.206)$ & $(0.300)$ & $(0.281)$ \\
Observations & & & \\
R-squared & 1,118 & 1,077 & 1,075 \\
Number of Industries & 0.188 & 0.303 & 0.283 \\
Industry FE & 86 & 86 & 86 \\
Year FE & Yes & Yes & Yes \\
\hline & Yes & Yes & Yes \\
\hline
\end{tabular}

Robust standard errors in parentheses

$* * * \mathrm{p}<0.01, * * \mathrm{p}<0.05, * \mathrm{p}<0.1$

The above analysis shows that regulation, lagged regulation, or changing regulation does not account for the decline in economic dynamism. It may be the case that only certain types of regulations are important for economic dynamism, and our focus on all regulations weakens that relationship. One could argue that large swaths of the CFR contain relatively meaningless text or legalese that does not affect the economy. Therefore, in our regulatory stringency index the importance of regulation is diluted by non-binding blocks of text. As mentioned in the previous section, our index is the aggregation of the probability a block of text is related to an industry multiplied by the number of restrictions in that block of text. A probability of association is calculated between each CFR part and all 3-digit NAICS industries. Consequently, relatively low probability industry associations could spread restrictiveness across unrelated industries. To address this we remove any contribution to the index where the probability of relevance is $5 \%$ or less. The regression results, reported in Table 6, still show no relationship between regulation and startups, job creation, or job destruction. 
Table 6: Dynamism and Industry Regulation, High Probability Industry Identification Only

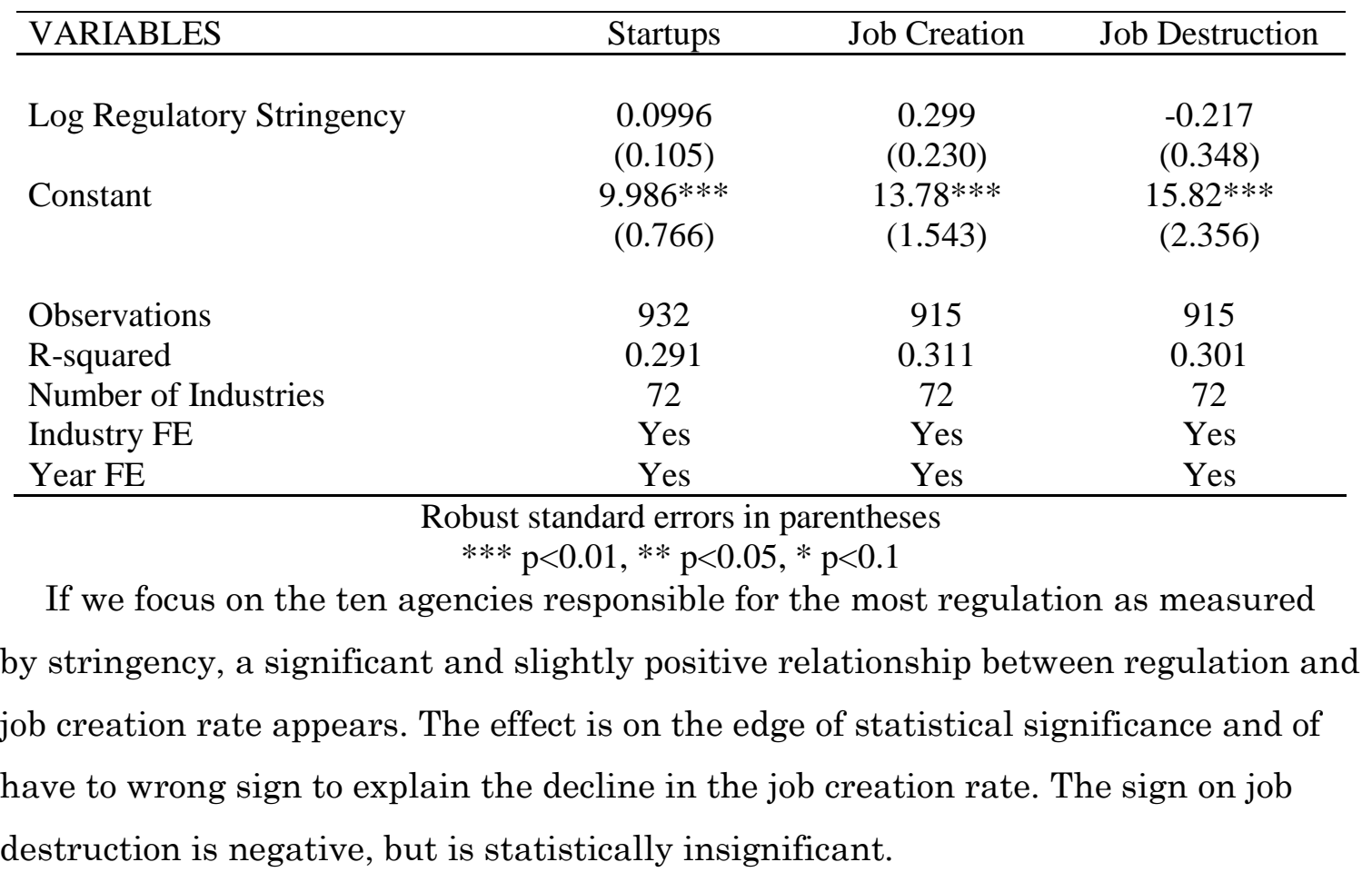


Table 7: Dynamism and Regulation: Top Ten Regulatory Agencies by Stringency of Regulation Only

\begin{tabular}{lccc}
\hline VARIABLES & Startups & Job Creation & Job Destruction \\
\hline & & & \\
Log Regulatory Stringency & 0.000461 & $0.00822^{*}$ & -0.00273 \\
& $(0.00307)$ & $(0.00437)$ & $(0.00453)$ \\
Constant & $10.71 * * *$ & $15.77 * * *$ & $14.29 * * *$ \\
& $(0.209)$ & $(0.311)$ & $(0.285)$ \\
Observations & 10,086 & 9,739 & 9,721 \\
R-squared & 0.190 & 0.302 & 0.283 \\
Number of Industries & 82 & 82 & 82 \\
Industry FE & Yes & Yes & Yes \\
Year FE & Yes & Yes & Yes \\
\hline \multicolumn{4}{c}{} \\
& Robust standard errors in parentheses & \\
& $* * * 0.01, * * \mathrm{p}<0.05, * \mathrm{p}<0.1$ &
\end{tabular}

\subsection{Digging Deeper - The Case of Manufacturing}

To better understand the relationship between changes in regulation and changes in measures of dynamism, we now focus son manufacturing industries. With RegData, we are able to identify manufacturing industries that experienced the largest increases and decreases in regulatory stringency between 1999 and 2011. Research has shown that regulation can have a significant effect on firm productivity and the ability to compete internationally. Most analyses of regulation in the manufacturing sector focus on the impacts of environmental regulations. Using plant level micro data, Gray and Shadbegain (1993), show that more heavily regulated plants have significantly lower productivity levels and slower productivity growth. Manufacturing regulation can also have significant impacts on the dynamics of the industry.

Table 7 shows the five manufacturing industries that experienced the highest and lowest percent change in our regulatory index from 1999 to 2011. Chemical, fabricated metals, and computers and electronics experience the greatest increase in regulatory stringency, while nonmetallic mineral products and machinery actually experienced a loosening in regulatory stringency. Figure 6 shows the regulatory index for these two groups. The average regulation index for the high group increases more than 50 percent, where the low group remains flat from 1999 through 2011. 
Table 8: Manufacturing - Change in Regulation Index 1999 to 2011

\begin{tabular}{|c|c|c|c|}
\hline $\begin{array}{l}\text { Largest Increase in } \\
\text { Regulation Stringency }\end{array}$ & & $\begin{array}{l}\text { Smallest Increase in } \\
\text { Regulation Stringency }\end{array}$ & \\
\hline Name (NAICS Code) & $\begin{array}{l}\text { Percent } \\
\text { Change }\end{array}$ & Name (NAICS Code) & Percent Change \\
\hline Chemical (325) & 73.07 & $\begin{array}{l}\text { Nonmetallic Mineral } \\
\text { Product (327) }\end{array}$ & -9.41 \\
\hline $\begin{array}{l}\text { Fabricated Metal Product } \\
\text { (332) }\end{array}$ & 61.41 & Machinery (333) & -2.37 \\
\hline $\begin{array}{l}\text { Computer and Electronic } \\
\text { Product (334) }\end{array}$ & 59.57 & $\begin{array}{l}\text { Printing and Related } \\
\text { Support Activities (323) }\end{array}$ & -0.36 \\
\hline $\begin{array}{l}\text { Beverage and Tobacco Product } \\
\text { (312) }\end{array}$ & 52.22 & Food (331) & 0.1 \\
\hline Primary Metal (331) & 50.67 & Paper (332) & 7.5 \\
\hline
\end{tabular}

Figure 6: Manufacturing Industries with Highest and Lowest Change in Regulatory Stringency

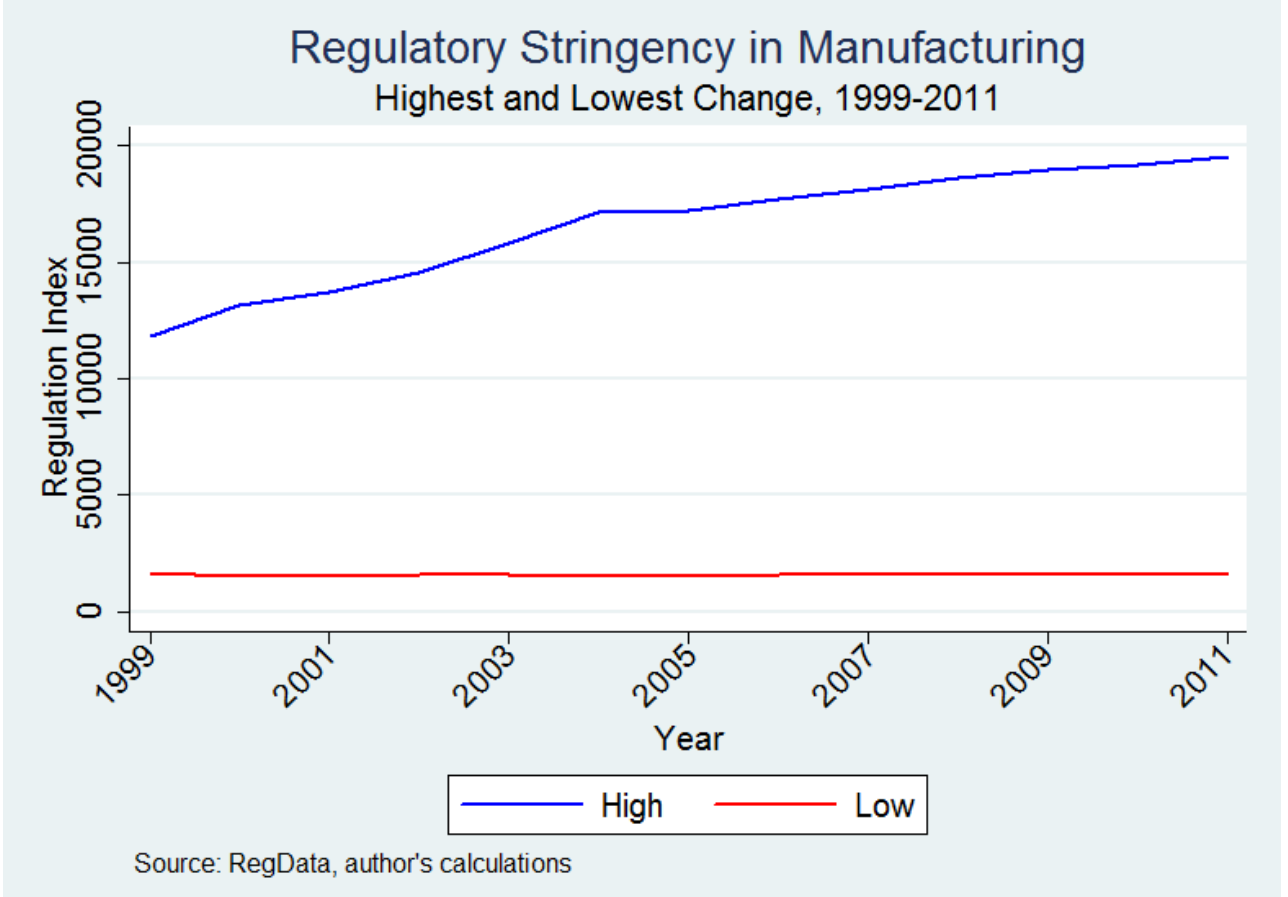

Figure 7 shows the startup rates for those industries that saw the largest and smallest percentage change in regulatory stringency. Visually, we can see that the tends for both groups track each other fairly well, with the industries seeing the greatest increase in regulatory stringency also having higher startup rates. A similar story appears in the job creation and destruction rates for these two groups. 
Figure 8 shows that job creation and destruction rates follow very similar trajectories, experiencing the same peaks and troughs, despite the fact that these groups of industries saw very different trends in regulatory stringency. The fact that trends in startups, job creation, and job destruction follow a similar path for both groups suggest that other causes are driving the changes in dynamism. These patterns also appear when focusing on retail trade, where the trends in dynamism for industries experiencing large and small changes in regulatory stringency are nearly identical.

Figure 7: Startups for Manufacturing

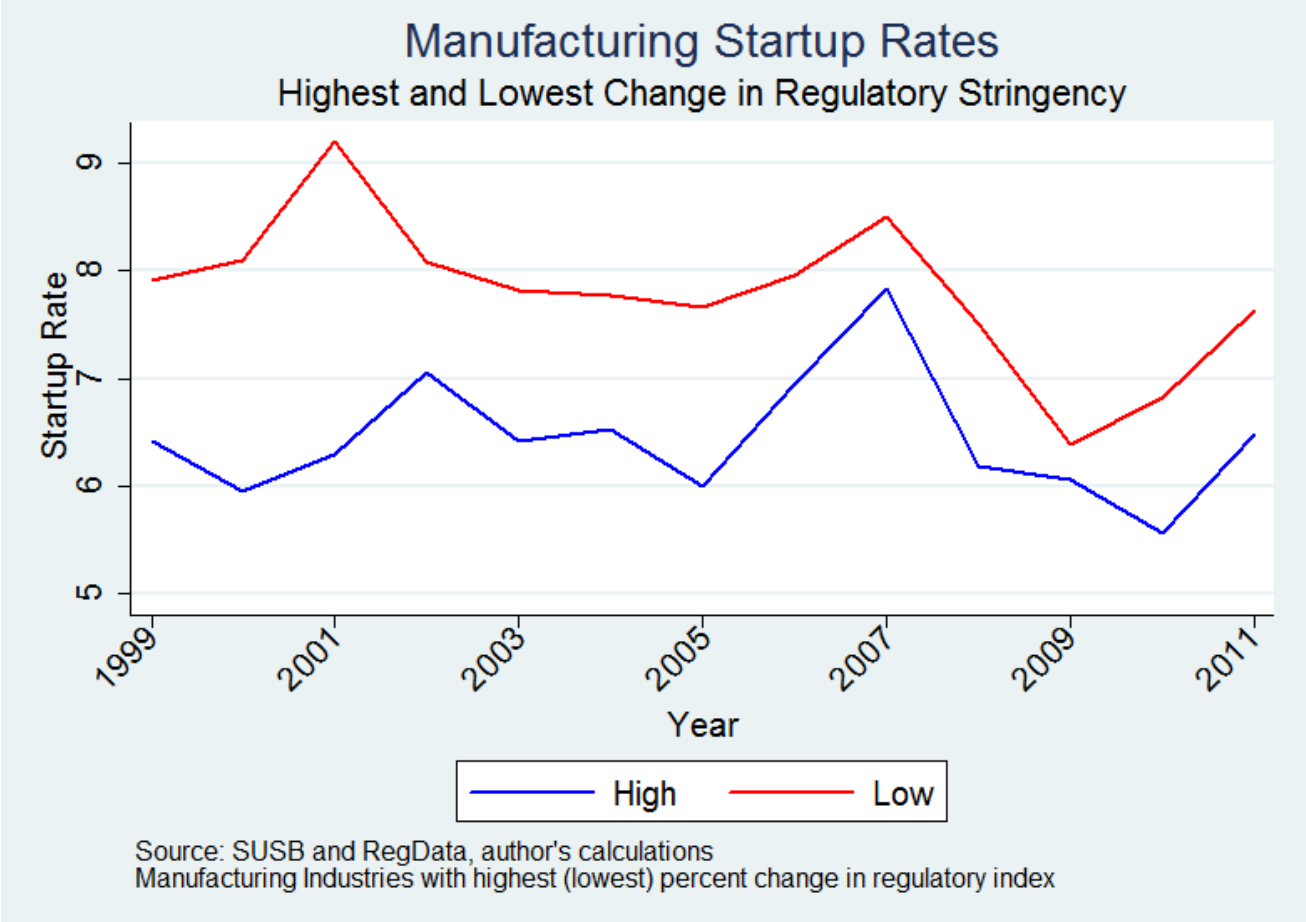

Figure 8: Job Creation and Destruction in Manufacturing 


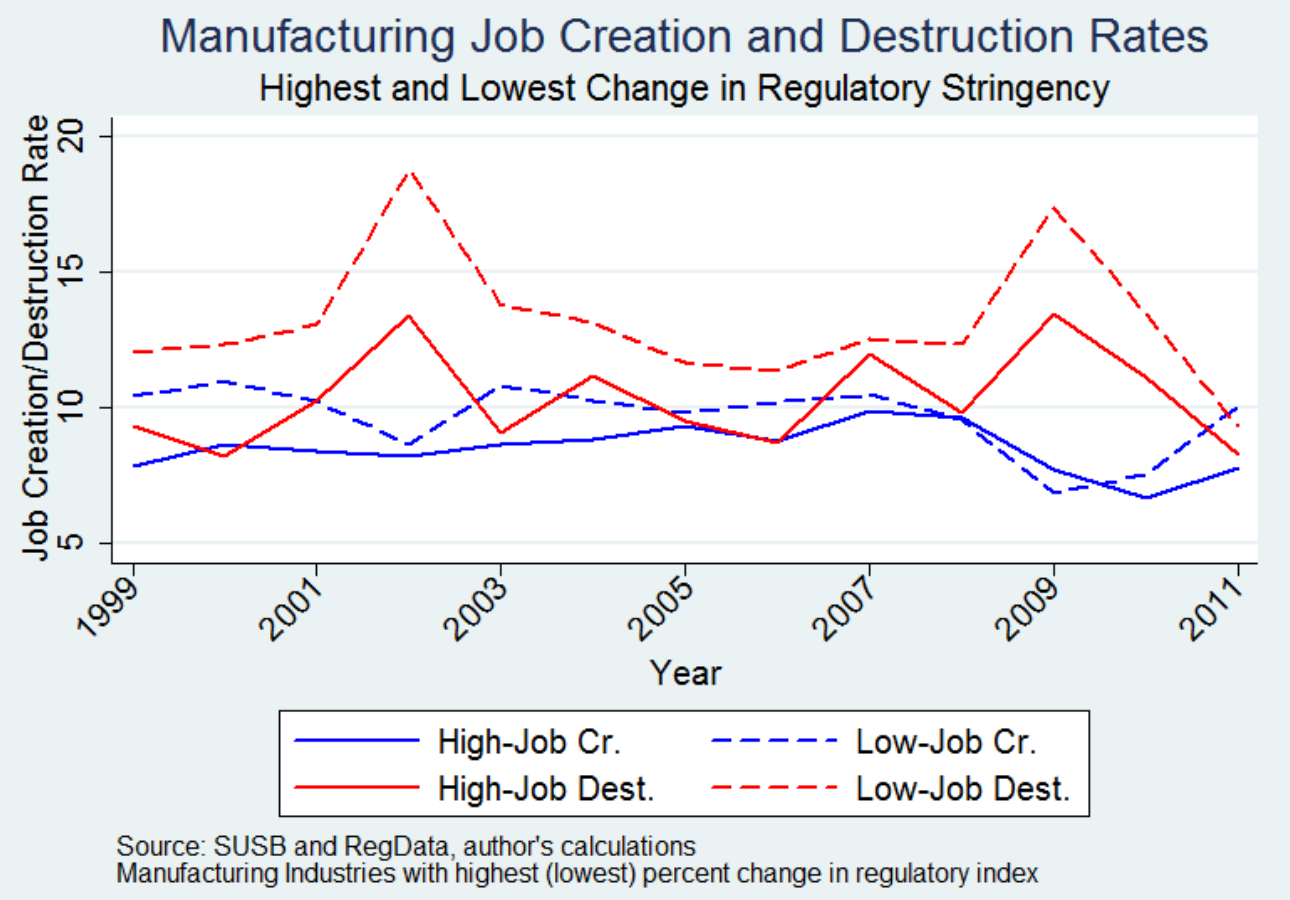

\section{Non-Federal Regulation, Technology, Globalization and other Causes of Declining Dynamism}

We find that federal regulation is not a major cause of declining U.S. business dynamism. Federal law is the most extensive and widely-discussed source of regulation but other sources, such as state-based legislation or common-law judicial interpretation, may also be important for understanding trends in dynamism. Davis and Haltiwanger (2014), for example, find that job reallocation rates are lower in states whose common-law courts weakened the employment at-will doctrine and they suggest that state-based minimum wages may also have decreased dynamism. The employment at-will doctrine and minimum wages affect some industries more than others, however, so it would be useful to investigate whether these factors can be used to understand trends in dynamism by industry.

A variety of other reasons suggest that regulation may play only a small role in the decline in dynamism. If we look around the world, for example, the most common type of regulations that impede dynamism are those that prevent firms from growing larger. The U.S. economy, however, hosts the largest firms in the world, which are growing even larger. Furthermore, larger firms are more productive on average and the positive relationship between size and productivity is 
strongest in the U.S. (Haltiwanger 2012). If instead regulation were preventing small firms from growing large, then we would expect startup size to be increasing. Instead, we observe no trend towards increased entrant size (Haltiwanger, Jarmin, \& Miranda 2013).

Another suggestive piece of evidence is that the decline in dynamism does not appear to be limited to the United States (Criscuolo, Gal \& Menon 2014). Broad trends in technology could explain declining rates of dynamism across developed economies. One reason to start a new firm, for example, is to implement a new idea. If progress on the technological frontier is slowing, then entrepreneurs would see fewer new ideas to be profitably implemented and would therefore be less likely to start a new firm (Goldschlag and Tabarrok 2015). Similarly, Hathaway and Litan (2014) argue that much of the decline in the rate of new firm growth can be accounted for in the United States by broad trends in the rate of population growth.

It should also be kept in mind that many measures of declining dynamism are associated with greater GDP per capita. For example, on average there are fewer entrepreneurs and more large firms in more developed economies both crosssectionally and over-time (Bento and Restuccia 2014, Lucas 1978, Poschke 2014). Improvements in information technology may be increasing the ability of large firms to adapt to shocks. Creative destruction brings benefits but at the price of bankruptcies, unemployment, and worker reallocation. If information technology can allow creative destruction to be internalized to the firm rather than the industry this may increase welfare. Declining dynamism and increasing stability are but two ways of naming the same thing.

We also may be mis-measuring dynamism. As already noted, a great deal of internalized creative destruction or the remaking and restructuring of large firms is not captured by business dynamics statistics. Nor is globalized dynamism. The great majority of Apple's approximately 750 suppliers, for example, are located in Asia. The Apple eco-system, however, is not static. With each iPhone iteration, Apple drops some suppliers and adds others but as this dynamism occurs abroad it isn't measured in US statistics. ${ }^{4}$

${ }^{4}$ We discuss these issues at greater length in Goldschlag and Tabarrok (2015). 


\section{Conclusions}

The decline in economic dynamism appears unsettling because theory suggests that reallocation plays an important role in economic efficiency. There are solid theoretical reasons to suspect that regulation may deter entry and slow the reallocation of labor. To investigate the extent to which the decline in entrepreneurship can be attributed to increasing regulation, we utilize a novel data source, RegData, which uses text analysis to measure the extent of regulation by industry. Our analysis suggests that Federal regulation is not a major cause of the decline in US business dynamism.

To the extent that Federal regulation is not the cause of declining dynamism, attention should flow to other sources of regulation such as state legislation and judicial regulation through the common law. Greater attention should also be given to deeper forces that may reduce dynamism such as a slowdown in the technological frontier that reduces the flow of new ideas ready to be profitably implemented. Technology, especially information technology, may also be changing the nature of dynamism in ways that are difficult to measure. The restructuring and rearranging of large firms, for example, can greatly improve the allocation of resources but is not currently well measured. The integration of business dynamic statistics globally would also give us a greater grasp on global dynamism, which may be increasing even as measured national dynamism decreases. 


\section{Appendix A - RegData Example}

As an example, the highest probability hit for the Mining (except oil and Gas) industry goes to this section in the CFR.

2010 Title 30 - Mineral Resources

SUBCHAPTER K-PERMANENT PROGRAM PERFORMANCE STANDARDS PART 819—SPECIAL PERMANENT PROGRAM PERFORMANCE STANDARDSAUGER MINING

$\S 819.1$ Scope.

This part sets environmental protection performance standards for surface coal mining and reclamation operations involving auger mining.

$\S 819.11$ Auger mining: General.

(a) Auger mining operations shall be conducted in accordance with the requirements of part 816 of this chapter, except as provided in this part.

(b) The regulatory authority may prohibit auger mining, if necessary to-

(1) Maximize the utilization, recoverability, or conservation of the solid-fuel resource, or

(2) Protect against adverse water-quality impacts.

$\S 819.13$ Auger mining: Coal recovery.

(a) Auger mining shall be conducted so as to maximize the utilization and conservation of the coal in accordance with $\S 816.59$ of this chapter.

(b) Auger mining shall be planned and conducted to maximize recoverability of mineral reserves remaining after the operation and reclamation are complete.

(c) Each person who conducts auger mining operations shall leave areas of undisturbed coal, as approved by the regulatory authority, to provide access for future underground mining activities to coal reserves remaining after augering is completed, unless it is established that the coal reserves have been depleted or are so limited in thickness or extent that it will not be practicable to recover the remaining coal. This determination shall be made by the regulatory authority upon presentation of appropriate technical evidence by the operator. 


\section{References}

Bartelsman, E., Haltiwanger, J., \& Scarpetta, S. 2013. Cross-Country Differences in Productivity: The Role of Allocation and Selection. American Economic Review, 103(1): 305-34.

Bento, P., \& Restuccia, D. 2014. Misallocation, Establishment Size, and Productivity. Working Paper no. tecipa-517. University of Toronto, Department of Economics. Retrieved from https://ideas.repec.org/p/tor/tecipa/tecipa-517.html

Bertrand, M., \& Kramarz, F. (2001). Does entry regulation hinder job creation? Evidence from the French retail industry (No. w8211). National Bureau of Economic Research.

Coffey, B., McLaughlin, P. A., \& Tollison, R. D. (2012). Regulators and Redskins. Public Choice, 153, 191-204.

Criscuolo, C., Gal, P. N., \& Menon, C. 2014. The Dynamics of Employment Growth. OECD Science, Technology and Industry Policy Papers. Paris: Organisation for Economic Co-operation and Development. Retrieved from http://www.oecdilibrary.org/content/workingpaper/5jz417hj6hg6-en

Davis, S. J., Faberman, R. J., \& Haltiwanger, J. (2012). Labor market flows in the cross section and over time. Journal of Monetary Economics, 59(1), 1-18.

Davis, S. J., Faberman, R. J., Haltiwanger, J., Jarmin, R., \& Miranda, J. (2008). Business volatility, job destruction, and unemployment (No. w14300). National Bureau of Economic Research.

Davis, S. J., \& Haltiwanger, J. 2014. Labor Market Fluidity and Economic Performance. Working Paper no. 20479. National Bureau of Economic Research. Retrieved from http://www.nber.org/papers/w20479

Davis, S. J., Haltiwanger, J. C., \& Schuh, S. (1998). Job creation and destruction. MIT Press Books, 1.

Dawson, J., \& Seater, J. (2008). Federal Regulation and Aggregate Economic Growth. Working Paper.

Decker, R., Haltiwanger, J., Jarmin, R., \& Miranda, J. (2014). The role of entrepreneurship in US job creation and economic dynamism. The Journal of Economic Perspectives, 28(3), 3-24. 
Eslava, M., Haltiwanger, J., Kugler, A., \& Kugler, M. (2010). Factor adjustments after deregulation: panel evidence from Colombian plants. The Review of Economics and Statistics, 92(2), 378-391.

Foster, L., Haltiwanger, J., \& Krizan, C. J. (2006). Market selection, reallocation, and restructuring in the US retail trade sector in the 1990s. The Review of Economics and Statistics, 88(4), 748-758.

Gray, W. B., \& Shadbegian, R. J. (1993). Environmental regulation and manufacturing productivity at the plant level (No. w4321). National Bureau of Economic Research.

Haltiwanger, J. (2012). Job creation and firm dynamics in the United States. In Innovation Policy and the Economy, Volume 12 (pp. 17-38). University of Chicago Press.

Haltiwanger, J., Jarmin, R. S., \& Miranda, J. (2013). Who creates jobs? Small versus large versus young. Review of Economics and Statistics, 95(2), 347-361.

Haltiwanger, John, Ron Jarmin, and Javier Miranda. 2009. "Business Dynamics Statistics: An Overview." Kauffman Foundation: Other Research. Available at SSRN: http://ssrn.com/abstract=1456465.

Hathaway, Ian, \& Litan, Robert. (2014). What's Driving the Decline in the Firm Formation Rate? A Partial Explanation. The Brookings Institution.

Hopenhayn, H., \& Rogerson, R. (1993). Job turnover and policy evaluation: A general equilibrium analysis. Journal of political Economy, 915-938.

Hsieh, C.-T., \& Klenow, P. J. 2009. Misallocation and Manufacturing TFP in China and India. The Quarterly Journal of Economics, 124(4): 1403-1448.

Lucas, R. E., Jr. 1978. On the Size Distribution of Business Firms. The Bell Journal of Economics, 9(2): 508-523.Mulligan, C., \& Shleifer, A. (2005). The Extent of the Market and the Supply of Regulation. Quarterly Journal of Economics, 120, 14451473.

Olley, G. S., \& Pakes, A. (1996). The Dynamics of Productivity in the Telecommunications Equipment Industry. Econometrica: Journal of the Econometric Society, 1263-1297.

Poschke, M. 2014. The Firm Size Distribution Across Countries and Skill-Biased Change in Entrepreneurial Technology. SSRN Scholarly Paper no. ID 2403128. 
Rochester, NY: Social Science Research Network. Retrieved from http://papers.ssrn.com/abstract $=2403128$

Syverson, C. 2004. Market Structure and Productivity: A Concrete Example. Journal of Political Economy, 112(6): 1181-1222.

Syverson, C. 2011. What determines productivity? Journal of Economic Literature. 49(2): 326-365.

Witten, I. H., \& Frank, E. (2005). Data Mining: Practical machine learning tools and techniques. Morgan Kaufmann. 